\title{
DEMOCRACIA E FILOSOFIA COMO LEGADOS CULTURAIS GREGOS: QUANDO PASSADO E PRESENTE SE ENCONTRAM
}

ORLOVSKI, Alessandro JABUR, Ana Maria Ribeiro Tanajura ${ }^{2}$

\begin{abstract}
RESUMO: O presente artigo pretende contribuir para a avaliação do legado cultural que o Ocidente recebeu da civilização grega antiga, principalmente a democracia e a filosofia. Evidencia que o conhecimento, algo tão procurado nos nossos dias, recebeu com a filosofia uma metodologia totalmente nova, já que só na Grécia Antiga ele foi visto como fim em si mesmo. Quanto à democracia, o artigo aponta as limitações históricas dessa primeira experiência, enfatizando, entretanto, a força da inovadora ideia de que o poder político poderia ser controlado pelo conjunto da sociedade. São analisadas também as condições históricas nas quais surgiram e se desenvolveram tanto a filosofia quanto a democracia, concluindo-se que a organização social escravista foi importante para esse processo. Conclui-se ainda que tanto a filosofia, da qual nasceria a ciência, quanto a democracia, da qual surgiriam os atuais sistemas modernos de governo, foram legados culturais essenciais para a construção do mundo ocidental da forma como o conhecemos hoje.
\end{abstract}

Palavras chave: Filosofia. Democracia. Civilização grega antiga.

SUMMARY: This article aims to contribute to the assessment of the cultural legacy that the West received from the Ancient Greek civilization, especially democracy and philosophy. It evidences that knowledge, something very sought nowadays, received with philosophy an entirely new methodology, since only in ancient Greece it was seen as an end in itself. As for democracy, the article points out the historical limitations of this first experience, emphasizing, however, the strength of the innovative idea that political power could be controlled by society as a whole. The historical conditions in which both philosophy and democracy emerged and developed are also analyzed, concluding that the social organization of slavery was important for this process. It also concludes that both philosophy, which would give birth to science, and democracy, which would give rise to the current modern systems of government, were cultural legacies essential to the construction of the western world as we know it today.

Keywords: Philosophy. Democracy. Ancient greek civilization.

\section{INTRODUÇÃO}

No momento em que o mundo assiste à crise da Grécia, torna-se oportuno lembrar o papel histórico desse povo e a imensa dívida cultural que temos para com ele. Esse artigo pretende contribuir para a avaliação do legado cultural que recebemos da civilização grega antiga.

Nesse sentido, desejamos lembrar aqui elementos fundamentais tais como a democracia e a filosofia, ambas respostas dadas a necessidades colocadas pela história.

A Grécia viveu a liberdade - e não apenas cunhou o termo - , que está para a filosofia tal como a Revolução Francesa está para a ideia moderna de democracia e de direitos humanos.

O conhecimento, algo tão procurado nos nossos dias, recebeu com a filosofia uma metodologia totalmente nova, uma vez que só na Grécia Antiga ele foi valorizado por si só, ou seja, visto não apenas como meio para obtenção de algo, mas como fim em si mesmo. Essa nova forma de busca do saber, que foi denominada "filosofia", revolucionou o mundo ocidental, do qual nós somos legítimos herdeiros.

\footnotetext{
${ }^{1}$ Graduação em História Licenciatura pela Faculdade de Filosofia, Ciências e Letras de Ituverava

${ }^{2}$ Mestre em Educação; Especialista em Gestão Escolar; Graduação em História e Pedagogia; Diretora de Ensino; Docente da FE/FFCL
} 
$\mathrm{Na}$ atualidade, a nação grega enfrenta uma crise típica do sistema capitalista em um mundo globalizado. Os tempos são outros, a história caminhou, mas a criatividade humana ainda poderá se manifestar, concorrendo para que soluções sejam encontradas. Seja como for, nós, ocidentais, somos herdeiros da cultura grega. Não nos esqueçamos do passado para que possamos saber com clareza quem somos no presente.

\section{A CIVILIZAÇÃO GREGA ANTIGA: SEU LUGAR E SEU TEMPO}

A pré-história grega remonta a cerca de 3000 anos a.C. Entretanto, só teremos algum documento escrito por volta do século X a.C., quando surgem as obras de Homero³: a Ilíada e a Odisséia. A filosofia surgiu depois disso, no século VII a.C., coincidentemente quando se formam as póleis, ou seja, o sistema de cidades-estados que marcaria a organização política grega. Tanto a pólis ${ }^{4}$ quanto a filosofia são marcas de uma das mais importantes características do povo grego: a independência, o zelo pela liberdade. Essa tendência ao individualismo favoreceu a criação da democracia em algumas póleis, notadamente Atenas.

Pode-se dizer que a filosofia e a independência estão estritamente correlacionadas, tanto é que em Atenas verificou-se o apogeu tanto da democracia quanto da filosofia.

Pode-se ainda considerar que os atenienses em geral consideraram a democracia a melhor opção de governo e lutaram por ela. Paralelamente, os gregos, como um todo, lutaram por sua liberdade e independência. Guerras $^{5}$ não faltaram na história da Grécia Antiga, que se encerra oficialmente após o chamado período helenístico (323 - 31 a C.). Depois disso, ocorreu dominação romana que se estendeu até o final da Idade Antiga, em 476 d.C.. O curioso é notar que, apesar de derrotada militarmente, foi a Grécia que saiu vitoriosa no campo cultural. Ela tinha muito mais a ensinar e aqueles que a dominaram tiveram que se curvar à sua superioridade cultural.

Geograficamente a Grécia é uma realidade insular, onde as atividades campesinas tornam-se difíceis pelo excesso de acidentes em seu terreno. Isso faz com que sejam buscados outros modos para interagir com o meio. Tal realidade colocou o mar como um importante elemento natural para os gregos, seja econômico, seja também filosófico. Assim Tales, o primeiro filósofo, propôs que o princípio de tudo seria a água e que o mundo repousaria sobre ela.

Ainda hoje o mar é fundamental aos gregos. Ele é importante na economia (para transporte, turismo, pesca); mas também na rica tradição cultural grega.

Na Antiguidade, nos aspectos comercial e cultural, a localização também foi muito relevante porque possibilitou desde cedo o contato com outras culturas, o que agiu como o fermento na massa. Foram semeadas novas ideias, abriram-se novas possibilidades, apontaram-se novos horizontes devido à condição peculiar de liberdade religiosa e política das quais os gregos gozavam.

\footnotetext{
${ }^{3}$ A tradição nos diz que essas obras teriam sido escritas pelo aedo cego Homero. Entretanto, os estudos da atualidade demonstram que as obras atribuídas a ele foram escritas na realidade por vários autores diferentes em momentos históricos diversos. Portanto, temos muitos "homeros". Mas tanto a Ilíada, quanto a Odisseia são importantes patrimônios da literatura mundial, fundamentais também para o conhecimento histórico. Por esses poemas ficamos conhecendo como eram as guerras, quais eram os valores daquele povo, sua religião, sua sociedade, etc.

${ }^{4}$ A pólis era uma Cidade-Estado independente. Cada uma delas tinha seu próprio sistema de governo, suas leis e costumes, que poderiam ser diferentes de todas as demais. Essa instituição revela uma das características principais dos gregos antigos: seu individualismo. Assim a história registra experiências de governos aristocráticos, de tiranias e democracias em diferentes póleis e em diferentes épocas. O que unia os gregos antigos não era um governo unificado, mas sim aspectos culturais como a religião, a língua, as olimpíadas.

${ }^{5}$ Os ciclos de guerras mais importantes foram as Guerras Greco-Pérsicas (499 - 475 a. C.), em que os gregos venceram o Império Persa e as Guerras do Peloponeso (431 - 338 a. C.), durante as quais as cidades gregas disputaram entre si a hegemonia. As destruições causadas pelos conflitos militares marcam o início do processo de decadência da civilização grega.
}

Nucleus, v.10, n.1, abr.2013 
Por outro lado, as condições históricas foram fundamentais. A civilização grega antiga viveu sob o sistema que os estudiosos marxistas denominaram de "modo de produção escravista", ou seja, o sistema econômico e a organização social se apoiaram sobre o trabalho escravo. Na prática, isso significava que os cidadãos, proprietários da terra, não precisavam trabalhar. Para isso existia a mão de obra escrava, sempre disponível.

$\mathrm{Na}$ verdade, os gregos antigos desprezavam o trabalho, principalmente o trabalho manual. Ao contrário da burguesia moderna, que passou a ver no trabalho uma forma de libertação e culto a Deus, o grego antigo, de certa forma, identificou o trabalho à escravidão, e não tolerava nenhuma ameaça à sua liberdade.

Aristóteles, por exemplo, teve a preocupação de definir a liberdade. Afirmou que o que marca o homem livre "é que ele não vive sob a coação de outro" (apud Finley, 1989, p. 106). Essa noção esconde a ideia de que o trabalho assalariado era, de certa forma, vergonhoso e devia ser evitado pelos cidadãos, já que seria uma forma de "submissão a outro" Também Platão se manifestou desfavoravelmente ao trabalho, afirmando: "o trabalho é alheio a qualquer valor humano e em certos aspectos parece mesmo ser a antítese daquilo que é essencial ao homem." (apud Anderson, 1984, p. 110) Nas palavras do historiador Moses Finley (1989): "não havia contradição, em suas mentes, entre liberdade para alguns e falta de liberdade (parcial ou total) para outros, nenhuma noção de que todos os homens nascem livres" (p. 85). Constata-se assim a grande "incapacidade do mundo antigo de imaginar que podia existir uma sociedade civilizada sem escravos" (p. 111). Na verdade, para os gregos (e também para os romanos), a escravidão era uma realidade da vida, já posta assim desde sempre e que não comportava críticas.

Portanto, a escravidão foi elemento básico na civilização grega! E, ao "descobrirem” o uso intensivo da escravidão como força básica de trabalho de sua sociedade, os gregos também "inventaram" a liberdade. Foram capazes de criar o sistema democrático e desenvolveram ao mesmo tempo as noções de liberdade e de escravidão ${ }^{7}$.

Verifica-se assim que as condições sociais e geográficas foram importantes para que os gregos exercessem toda a sua criatividade e fizessem nascer a democracia e a filosofia. Ambas surgiram como atividades praticadas pela classe aristocrata e só por ela. A massa não tinha tempo e nem condições para tanto ${ }^{8}$.

Nesse sentido, Santos (2012) observa a correlação entre democracia e filosofia, bem como suas limitações, ao analisar a teoria da aísthesis que Platão oferece ao sofista Protágoras:

É, no entanto, marcando a diferença entre a posição filosófica e o fazer da sofística que o ateniense fornece elementos para justificar um modelo político de sustentação da pólis, a democracia. A justificação, porém, não significa a aceitação desse sistema; antes, ela é o mapa que fornece a Platão os pontos que devem ser atacados, visto esse sistema não se amparar no cânone da verdade, mas na coerência do melhor discurso. Por isso se faz importante que o homem-medida protagórico seja inserido na primeira abordagem platônica ao que seja epistéme. Em 166a-168c do Teeteto, Platão descreve estrategicamente, a partir da clássica defesa de Protágoras, o que possibilita a vida

\footnotetext{
${ }^{6}$ Segundo Anderson (1984), o Modo de Produção Escravo ou Escravista caracterizou-se pela predominância da mão de obra escrava, sobre a qual repousava todo o sistema de produção da sociedade. O ser humano tornou-se uma mercadoria e como tal era tratado. A liberdade e o brilhantismo da arte, da literatura e da filosofia na Grécia Antiga deveram muito a esse sistema. Isso porque os grandes artistas e filósofos puderam ver-se livres do trabalho braçal e puderam dedicar seu tempo à criação das grandes obras que constituem ainda hoje uma herança importante para a humanidade.

${ }^{7}$ Dizia Platão em "A República": "É, penso eu, a partir da mais extrema liberdade que nasce a maior e mais rude escravidão" (apud Agostini, 2008, p. 235).

${ }^{8}$ A esse respeito, Agostini (2008) considera que Platão desprezava e atacava a política das massas, considerando-a causadora de inúmeros males, produto da degeneração do melhor tipo de governo, que seria, segundo ele, o governo aristocrático filosófico. Essa visão de Agostini vem ao encontro de nossa argumentação, segundo a qual a filosofia surgiu de fato como atividade restrita a uma classe socialmente privilegiada, em uma sociedade desigual.
} 
"coerente" na pólis. O homem descrito por uma epistemologia, quiçá uma fenomenologia, agora é compreendido por meio da comunidade. A política justifica e pede pela melhor ação, e esta, por sua vez, se referenda na prática do melhor discurso, advindo da opinião da maioria dos cidadãos. Onde impera a lei da maioria não se vê um discurso que elege o verdadeiro em detrimento do falso, mas aquele que prefere o melhor em vez do pior. (p. 80)

\section{O SURGIMENTO DA DEMOCRACIA EM ATENAS}

A democracia (Demos: povo; Kratos: poder) foi inventada pelos gregos que viam nela uma forma de viver em liberdade. A palavra significa "governo do povo". Pode-se perguntar: até que ponto o povo estava no poder na Grécia Antiga? Cerqueira (2002) considera que "foi entre os gregos que se desenvolveu a noção de que o direito é coisa pública, confeccionada e controlada pelo conjunto da comunidade” (p. 7). Mas, será que havia de fato liberdade? Como sempre, é difícil analisar a realidade vivida por uma civilização separada de nós por tantos séculos sem incorrermos em anacronismo. Na tentativa (talvez vã) de superarmos esse obstáculo, ouçamos as palavras de Cerqueira (2002):

Na Grécia Antiga, a partir do séc. VIII a.C., viveu-se um processo absolutamente original do ponto de vista político. Ao fim de um longo período denominado por $\mathrm{M}$. Finley como a Idade de Ulisses, pois se nos apresenta por meio das narrativas épicas da Ilíada e Odisséia, a realeza homérica entra em crise, cedendo espaço à aristocracia, que progressivamente se apropria das prerrogativas do poder, relegando aos descendentes da realeza apenas funções religiosas. Nesse período, o poder é repartido entre membros da elite militar e terratenente, descendentes da nobreza homérica, que desmembram o poder em três funções: militar, exercida pelo polemarco; administrativa, pelo arconte; e religiosa, pelo arconte basileus - ou seja, a figura do rei destituída de seus poderes políticos. (Aristóteles, A Constituição de Atenas, III.) Nesse primeiro passo, mesmo que ainda nas mãos da aristocracia, o poder começa a sair da esfera do privado - onde se localizava sob controle do rei - e avança no sentido do estabelecimento da ordem pública. O poder não é mais a pessoa; agora, o poder é a função. Para o exercício dessa, escolhe-se (sic) por eleição indivíduos que exercerão esses cargos por um período determinado. O poder - a arché - passa então a circular entre a comunidade que possuía plenos direitos de cidadania, que correspondia, pelo menos até finais do séc. VII (no caso ateniense), à elite terratenente e militar. Nessa transição entre a monarquia e a nascente pólis aristocrática, surge o conceito de que o poder do Estado devia estar sujeito ao interesse público e que esse público (a comunidade cidadã) devia exercê-lo por si mesmo, e não delegar a uma autoridade real com poderes ilimitados. Esse público, esse grupo de cidadãos, restringia-se, na cidade arcaica, a um reduzido grupo de cidadãos ricos com monopólio das funções militares, administrativas e religiosas. (p.3)

Esse processo é fundamental. O poder político passa das mãos de lideranças pessoais para a instância de um Estado de direito, no qual o interesse dos cidadãos é considerado prioridade. Com todas as restrições impostas pelo processo histórico, esse foi um avanço significativo, fundamental para nossa civilização ainda nos dias de hoje.

Entre os interesses dos cidadãos gregos figurava com destaque a liberdade. E aqui há questionamentos pertinentes. O que é liberdade? Ela é uma realidade possível? Será que somos livres atualmente? Finley (1984) pensa que "todos os homens [...] têm de um modo ou de outro a sua liberdade limitada em conseqüência de viverem em sociedade. A liberdade absoluta é um sonho vão (e seria, de qualquer modo, psicologicamente intolerável)" (p. 119).

Mas os gregos acreditavam na liberdade e pensaram em uma forma inovadora de resolver os conflitos que surgem entre todas as pessoas que vivem juntas. A ideia básica era a de que todos os cidadãos poderiam participar da vida pública, do sistema político e das decisões tomadas na cidade. A maioria poderia decidir. 
Somente os homens adultos que fossem cidadãos atenienses e que tivessem terminado serviço militar poderiam votar em Atenas. Os cidadãos deveriam ser $15 \%$ da população, ou seja, cerca de 30.000 em um total de 200.000 pessoas, aproximadamente ${ }^{9}$.

Assim, é importante - e curioso! - observar as limitações desse primeiro modelo de democracia. Isso porque ela era na verdade um sistema machista, xenófobo e escravista. Em outras palavras, dele estavam excluídos as mulheres, os estrangeiros e os escravos. Para nós na atualidade esse modelo não serve! Nós acreditamos que todos têm o direito de votar e ser votados. No Brasil, assim como em todos os Estados democráticos atuais, todos são cidadãos desde o momento em que nascem! $\mathrm{E}$ isso não acontecia na Grécia Antiga. Lá, mesmo as crianças não eram necessariamente respeitadas e os pais podiam matar, abandonar ou vender seus filhos sem nenhum problema! (FLORENZANO, 1996) Os direitos estavam restritos apenas aos cidadãos.

Essa estranha experiência inicial grega pode ser acusada de trair aquilo que consideramos como os verdadeiros princípios democráticos. Entretanto, um olhar mais atento para a história nos ajuda a entender melhor a situação. Vejamos a legislação ateniense segundo a análise do historiador Giordani (1972):

A constituição de Sólon repousa, com efeito, essencialmente, na idéia de que os direitos políticos são proporcionados à riqueza. Há nisso um princípio que pode, à primeira vista, parecer pouco democrático; cumpre, porém, não esquecer que a primeira condição do progresso da democracia era a destruição do inalienável privilégio do nascimento, porquanto a riqueza é apenas um fato e não se acha aliada de uma maneira invariável aos indivíduos ou às famílias. O privilégio concedido à riqueza é uma fase universal e necessária entre o privilégio de nascimento e a igualdade absoluta. É preciso, além disso, observar que a riqueza se tornava precisamente, então, pelo espontâneo desenvolvimento do comércio e dos negócios, e por algumas leis do próprio Sólon, mais facilmente acessíveis a numerosos cidadãos, de maneira que a substituição de um princípio por outro correspondia, na realidade, a um progresso no sentido da igualdade. (p.168.)

A convocação para participar do conselho do povo chamava-se Eclésia. Nela o cidadão tinha os seguintes direitos: “... gozavam de ampla liberdade de palavra, podendo emitir suas opiniões, apresentar projetos, debater proposições, etc." (GIORDANI, 1972, p.173). Esse clima de liberdade propiciava o debate e o confronto entre ideias diferentes. Platão, por exemplo, embora fosse um ativo cidadão ateniense, não era adepto do regime democrático. Assim:

[...] o regime democrático não é um regime justo segundo a metafisica platônica, consequentemente não é um regime capaz de proporcionar a felicidade dos indivíduos sob sua égide. Havendo divisão entre ricos e pobres, os desejos individuais sobrepondose aos da coletividade, o modelo democrático promove um meio infeliz e desarmônico de agrupamento popular. Se só é possível conceber de maneira intrínseca "justiça, educação e felicidade", no governo em que o povo é senhor, tais mudanças mutuamente suprimem-se. Não se pode pensar em uma comunidade democrática feliz, porque não há comunidade democrática justa; a felicidade de uma comunidade democrática é impensável, porque aí não há educação e, por conseguinte, não há justiça. (AGOSTINI, 2008, p. 233)

Se nem todos apoiavam o regime democrático em Atenas, os cidadãos gregos, entretanto, sempre permaneceram amantes da liberdade. Zelosos dela, fizeram-na caminhar lado a lado com a consciência cívica, já que cada cidade com sua região próxima formava um Estado politicamente independente dos demais (as duas cidades gregas que representaram bem as disparidades entre elas foram Atenas e Esparta).

Esta realidade foi uma "faca de dois gumes". Por um lado, falava-se a mesma língua, cultuavam-se os

${ }^{9}$ Finley (1984) discute esse assunto, levantando hipóteses numéricas propostas pelos historiadores a esse respeito. 
mesmo deuses; por outro, faltava unidade nacional, o que implicava em que cada cidade só se preocupasse com seu próprio desenvolvimento. Logo, o campo estava aberto para as disputas e rivalidades. Quando a necessidade não as impelia a alianças, as póleis em geral ou não se davam bem ou se atacavam abertamente.

Assim, permaneceu sempre o individualismo e o ideal de liberdade. Com relação à consciência livre dos gregos, Festugière (1953) nos diz:

La noción de libertad está inmediatamente vinculada, en Grécia, a La de demokratia, es decir al gobierno del pueblo por el pueblo (demos): "El fundamento del régimen democrático es la libertad", dice Aristóteles (Pol., Z 2, 1317 a 20), después de Paltón (Rep., VIII, 557 b 3, 502 b 6).

$[\ldots]$

La alianza entre "libertad" y "democracia" implica pues, como se ve, dos privilegios: por un lado La libertad civil, en el sentido de que todo miembro de la cuidad, hijo de padres ciudadanos, se halla garantizado en su persona y en sus bienes mientras no infrija ninguna de las leyes civiles ni políticas del Estado, y por otro La libertad política, en cuanto el ciudadano, por el solo hecho de su nacimiento, y a reserva, evidentemente, de obedecer a las leyes, es apto para revestir todas las magistraturas públicas, ya sea que le correspondan por sorteo o que se le confíen por elección. Semejante régimen es distinto Del oligárquico o aristocrático en el que el poder solo pertenece a La clase restringida de los "ricos" o de los "mejores" (en sentido social) y Del régimen monárquico o tiránico, en que el hombre cuya decisión tiene fuerza de ley.

$[\ldots]$

“¿Cuál eres el objeto relativamente al cual el hombre griego es libre, es decir, está libertado, o cual es el cautiverio de qué se ha emancipado?" El griego se ha libertado, por una parte, en su misma persona, de las cadenas de la esclavitud que le ataban de hecho (en forma de servidumbre) o que constantemente le amenazaban con ligarle, dado lo precario de su condición material (esclavitud por deudas); y por otra parte, se ha libertado, en tanto que animal político, del dominio tiránico de los primeros dueños de Grecia, los reyes o los señores feudales que poseían la tierra. He aquí el sentido de la libertad entre los griegos. (p.9, 12-13)

Assim, em essência, a ideia de liberdade democrática reside no fato de que o poder está na totalidade de seus membros. Esta forma de governo implica que as decisões do Estado são tomadas com a participação do povo através de mecanismos que lhe conferem essa participação, quer de forma direta, quer indireta. A participação do povo confere legitimidade à escolha. Não são mais os deuses, nem os reis, quem decide.

Esta é a ideia moderna de democracia. Como já foi dito, em Atenas era um pouco diferente. Existia uma espécie de hierarquia de valor pessoal para participar das decisões. Os que podiam participar eram somente os demos. Mas o respeito às decisões tomadas em assembleia era tão grande que foi assim que a democracia terminou em Atenas: em 411 a.C., a assembleia ateniense votou a abolição do sistema democrático.

Encerrada no século V a.C., ela voltaria, muitos séculos depois, a ser o ideal político da modernidade.

De qualquer forma, a invenção da democracia foi uma grandiosa herança que recebemos dos gregos. Nós a aperfeiçoamos, mas é dos helenos o mérito de terem sido os primeiros a pensar nessa nova forma de governo. E eles devem ser lembrados também, entre outras coisas, por injetar no coração da humanidade a capacidade de pensar, de raciocinar. Deixaram como legado para a posteridade a tradição do logos.

\section{NASCE A FILOSOFIA: DO MITO AO LOGOS}

A filosofia no sentido de "amor à sabedoria" foi algo original dos gregos. Pode-se afirmar que seu surgimento provocou um tipo de revolução que deixou traços na história da humanidade, traços sentidos até os dias atuais. 
Ao estudarmos a história da Antiguidade, percebemos que elementos gregos podem ser encontrados em outras culturas, tais como a egípcia ou as culturas dos povos da Mesopotâmia que, aliás, alcançaram um nível de desenvolvimento bastante elevado antes do advento da civilização grega. Entretanto, com relação ao que o ocidente chamou de "filosofia" não há nada correlato.

Manifestações artísticas das mais diversas naturezas, crenças, cultos religiosos variados, habilidades técnicas notáveis, conhecimentos diversos, instituições militares e políticas existiram, seja entre os povos orientais que chegaram à civilização muito antes que os gregos, seja entre outros povos no decorrer da história da humanidade. Podem-se, inclusive, fazer algumas comparações - com certos limites - e tentar estabelecer em que medida os gregos são devedores de outros povos nos seus mais variados domínios.

Mas, a filosofia na Grécia clássica, ao menos no seu surgimento, não tem a concepção que hoje a ela atribuímos. "Amor à sabedoria", que é a clássica tradução da palavra filosofia (filo: amigo e Sofia: sabedoria), neste momento não é compreendida como o resultado do trabalho estritamente racional como pensará o mestre peripatético e será reafirmado pela modernidade ${ }^{10}$.

A ideia que se tem de filosofia quando esta é nascente é algo ainda muito ligado à dimensão mística, como nos mostra Reale (1999):

Digamos logo de início que a tradição sustenta ter sido Pitágoras o inventor do termo, o que, se não é historicamente verificável, é verossímil. O termo foi cunhado certamente por um espírito religioso, que pressupunha ser possível somente aos deuses uma "sophia" como posse certa e total, enquanto destacava que ao homem só era possível tender à "sophia", um contínuo aproximar-se, um amor jamais totalmente satisfeito dela, de onde justamente o nome filo-sofia, amor a sapiência. (p.28)

A ideia de uma filosofia totalmente oposta ao mito ou à religiosidade, com base no que vimos acima, é uma ideia moderna. A filosofia no momento de seu nascimento e posteriormente estará sempre em intensa tensão entre um pensamento mitológico religioso e um pensamento na esfera do lógos propriamente dito, uma tensão que futuramente implicará em uma substituição. Homero e Hesíodo serão deixados de lado como as grandes autoridades. Os mitos não mais serão fontes de conhecimento, ora porque cada povo tem os seus, ora porque são plausíveis de muita crítica. A ideia de necessidade se impõe contra a ideia de capricho dos deuses. Descobrem-se certas leis na natureza (temperaturas de ebulição e congelamento da água, peso de materiais que flutuam etc.) e surge a ideia de um princípio último de tudo. Ocorre um processo histórico gradativo.

Os problemas dos quais a nascente filosofia se ocupará são bem resumidos por Mora (2005):

[...] "O que é o 'ser' (a realidade do mundo)?", "Como pode ser conhecida a verdade (sem se consultarem os deuses ou o destino)?", "Em que linguagem ou mediante que faculdades se pode falar sobre o que é, na verdade 'o ser' (a realidade, o mundo)?" estas perguntas não são as únicas - especialmente a partir do chamado "período antropológico"; a filosofia grega interessou-se por questões acerca da natureza do humano, da linguagem, da sociedade, do Estado justo etc., mesmo que em muitos casos se considere que o ser humano era um componente ou elemento da realidade cósmica. (p.1081)

Essencial na filosofia grega é o conceito de lógos. Proveniente do verbo grego legein, logos é comumente traduzido por: expressão, pensamento, conceito, discurso, fala, verbo, razão, inteligência, lei,

\footnotetext{
${ }^{10}$ Lalande (1999, p.45) define filosofia como "Saber racional, ciência, no sentido mais geral da palavra". Japiassu e Marcondes (2008, p.108), por sua vez, observam que o termo "foi frequentemente usado para designar a totalidade do saber, a ciência em geral, sendo a metafísica a ciência dos primeiros princípios, estabelecendo os fundamentos dos demais saberes".
} 
princípio, norma. O significado do verbo grego legein é falar, dizer uma história. Assim logos é uma reunião, colheita de ideias com o intuito de se explicar claramente algo.

Essa claridade na explicação responde ao desejo de se ter respostas concretas. Por exemplo, ao se perguntar qual é a origem do universo, a resposta vem por meio de elementos objetivos físicos naturais, conhecidos por todos, não mais por meio de elementos religiosos, poéticos, nem sobrenaturais.

Os gregos, ao fazerem essa revolução cultural / intelectual, percebem que na natureza há ordem e harmonia, pois os seus movimentos são regulares, cíclicos, e nos fenômenos que nos rodeiam é possível ver constantes proporções. Assim se deduz que a ordem e a lei presentes na natureza são coisas intrínsecas a ela e percebe-se então que o universo não é um caos, mas antes é cosmos, no sentido de que é algo belo, organizado. Cientes de tudo isso, concluem que se pode explicar o universo.

Percebe-se então que as coisas que compõem o mundo são dotadas de qualidades permanentes e constantes (tal fato posteriormente será tratado com bastante propriedade pelo grande Aristóteles), às quais se denominam essência. A essência permanece, embora mudem algumas coisas superficiais. Esse conceito, portanto, supõe unidade entre as coisas frente à multiplicidade de seus estados e aparências.

Conhecer será então a capacidade de abstrair ${ }^{11}$ o comum e permanente das coisas que nos cercam no mundo. Os gregos entendiam que os sentidos não eram eficazes no processo do conhecimento e foi preciso um significativo esforço intelectual a fim de se captar o "ser" das coisas. Isso implicou em uma diferença radical entre a razão e os sentidos como fonte de conhecimento. Neste momento histórico é fundado o dualismo, que terá sua máxima expressão em Platão. Sobre isso, lê-se no verberte "Dualismo" do Dicionário de Filosofia de Cambridge (2006):

Doutrina segundo a qual a realidade consiste em duas partes diferentes. A dificuldade do dualismo está na aparentemente insuperável brecha entre duas ordens incomensuráveis de ser, que devem ser reconciliadas se a nossa suposição de que existe um universo compreensível deve ser justificada. O dualismo já é mostrado na divisão pré-socrática entre aparência e realidade; no domínio do ser devido a Platão e que contém Idéias eternas e o setor do vir-a-ser que contém as coisas que mudam. (p. 243-244)

Assim, a referência para os gregos neste momento, no que diz respeito a um conhecimento verdadeiro, será a matemática e a geometria, porque são essencialmente racionais e se pensava que estas podiam dar a melhor descrição da estrutura e das proporções das coisas.

Salientamos mais uma vez que os gregos criaram algo extremamente novo e de fundamental importância para o despertar da consciência humana: a filosofia. Essa contribuição não é meramente quantitativa, mas é qualitativa. Ter isso presente é importante para compreender por que todo o Ocidente tomou, com esse impulso dado pelos gregos, uma direção completamente diferente dos rumos da civilização do Oriente e por que a ciência só pôde nascer no Ocidente e não no Oriente.

Nesse sentido, concordamos com Silva e Ansai (2008) quando analisam o papel da filosofia na história:

Desde o século VI a. C., quando ocorreu o surgimento da Filosofia, ela foi posta como uma nova ordem de pensamento. No entanto, não podemos afirmar que o fato de ser uma nova ordem de pensamento seja suficiente para definir a filosofia. Nela, há liberdade de pensamento, portanto, se torna uma tarefa impossível encontrar uma definição pronta. Encontraremos, sim, uma constante busca pelo aprender a filosofar.

\footnotetext{
${ }^{11}$ Abstração: É a operação mediante a qual alguma coisa é escolhida como objeto de percepção, atenção, observação, consideração, pesquisa, estudo etc. e isolada de outras coisas com que está numa relação qualquer. [...] A A. é inerente a qualquer procedimento cognitivo e pode servir para descrever qualquer procedimento deste gênero. Com tal finalidade foi utilizada desde a Antiguidade. Aristóteles explica com A. a formação das ciências teóricas, isto é, da matemática, da física e da filosofia. (ABBAGNANO, NICOLA. Dicionário de filosofia. Martins fontes. São Paulo. 2007. Verberte: Abstração, p. 4).
}

Nucleus, v.10, n.1, abr.2013 


\section{$[\ldots]$}

Com efeito, entendemos que a filosofia é o meio pelo qual o homem se torna crítico, pois, é a partir do momento em que passa a pensar, refletir, analisar os conceitos da sociedade, que se vê como um membro com possibilidade de viver e de alterar o funcionamento desta. E, é somente assim que conseguimos expor idéias novas e interagir sobre o meio em que vivemos. Por conseguinte, não aceitamos exclusiva e unicamente o que nos é posto como certo a ser seguido. Sendo assim, quando começamos então, a filosofar, começamos também a ponderar a cotidianidade dos seres humanos. (p. 3) (sic)

Com a filosofia, começamos a pensar por nós mesmos, tornamo-nos críticos. E, a partir da reflexão sobre a realidade, podemos perceber que nossas ações têm consequências, que atuamos sobre a sociedade e sobre a natureza. Finalmente, tornando-nos conscientes disso, podemos agir e modificar a história. Esse é o potencial revolucionário da filosofia.

\section{FILOSOFIA: MATRIZ DA CIÊNCIA}

Quando os orientais quiseram beneficiar-se da ciência que o ocidente criou e de seus resultados, tiveram que se apropriar das categorias essenciais da lógica ocidental ou, pelo menos, de algumas delas. Foi precisamente a filosofia grega que criou essas categorias e essa lógica, ou seja, um modo de pensar totalmente novo, e, em função disso, a própria ciência.

O caminho até a filosofia foi bastante árduo. Os primeiros documentos históricos gregos, os já citados poemas homéricos, Ilíada e Odisseia, contêm elementos que os diferenciam de tudo o que nos foi legado pelas mais antigas culturas humanas. Eles têm uma imaginação rica e variada, transbordam em maravilhas, situações e eventos fantásticos, e raramente caem na descrição do monstruoso e disforme, como vemos em manifestações artísticas primitivas.

A imaginação homérica é bem estruturada segundo um sentido de harmonia, de uma justaposição entre as partes do todo, do limite da medida, traços esses que serão constantes na filosofia grega. Existe também a motivação constante nos poemas, no sentido de que o poeta busca sempre, mesmo que em nível fantástico-poético, as razões das coisas. Não há nele uma mera aceitação passiva da realidade, mas uma desenvoltura interior da ação, de fase a fase, sempre com um nexo entre causa e efeito.

A literatura grega antiga nos mostra que, ao contrário da mentalidade típica do homem oriental, que aceitava a realidade do mundo como dada pelos deuses, os gregos se propõem a modificá-la. Percebe-se o nascimento de uma nova forma de ver o mundo. Provavelmente esse é um dos motivos pelos quais a ciência surgiu com os gregos. Eles foram os primeiros a procurar entender o mundo de uma forma racional, libertandose da superstição. Os povos orientais viam o mundo como criação imutável, já que os deuses não apreciavam inovações. Na prática, entre os povos orientais, a tradição e a religiosidade dominaram a ciência. Entre os gregos, ao contrário, a curiosidade e a inventividade estiveram sempre presentes. Embora os deuses gregos fossem sempre mais fortes, os seres humanos os desafiaram. E desses desafios surgiu a ciência.

Torna-se pertinente aqui uma pausa para pensarmos sobre o conceito de ciência. Japiassu e Marcondes (2008) informam que a palavra significa "conhecimento" e que pode ser entendida como "saber metódico e rigoroso, isto é, um conjunto de conhecimentos metodicamente adquiridos, mais ou menos sistematicamente organizados, e suscetíveis de serem transmitidos por um processo pedagógico de ensino" ( $p$. $44)$.

Aceitando essa definição, pode-se afirmar que é com os gregos que o conhecimento se estruturou dessa forma a que chamamos científica. Para esse processo contribuíram, além da natural curiosidade intelectual dos gregos, a ausência de uma organização administrativa e religiosa com pautas rígidas de 
comportamento. Além disso, havia a tendência à reflexão, à argumentação e ao debate, o que os impeliu a comparar ideias.

Assim, a ciência nasceu da filosofia. Isso porque ainda não existia a separação entre as diversas áreas do conhecimento, como acontece hoje. Os que estudavam, pesquisavam tudo!

Outro ponto a ser observado é que a ciência grega, além de ser racionalista - e, portanto, independente de quaisquer superstições ou crenças religiosas —, também é independente do utilitarismo. Os estudos científicos eram realizados mesmo sem uma ideia prática sobre para o que serviriam no final das contas. Pesquisava-se pelo prazer de conhecer. Como já foi dito, era este um luxo reservado aos privilegiados. Nas palavras do historiador Hauser (1998):

Para a classe dominante grega e seus filósofos, a ociosidade total é a condição prévia de tudo o que é bom e belo - é o inestimável bem que, só por si, torna a vida digna de ser vivida. Somente aquele que dispõe do ócio pode alcançar sabedoria e liberdade de espírito, pode ser senhor da vida e gozá-la plenamente. (p. 116)

Assim, com os pré-socráticos em uma sociedade escravista iniciou-se a filosofia. E estes foram os primeiros filósofos no sentido fundamental da palavra. Todas as posições da filosofia ocidental (ao menos na metafísica - a ciência das coisas primeiras) foram tomadas por eles e, portanto, a história da filosofia posterior consiste essencialmente em repetir e refinar o que estes grandes pensadores descobriram. Os filósofos gregos desencadearam essa grande mudança histórica e cultural, foram mestres e continuam sendo até os dias de hoje.

\section{CONSIDERAÇÕES FINAIS}

Podemos concluir, portanto, que tanto a filosofia, da qual nasceria a ciência, quanto a democracia, da qual surgiriam os atuais sistemas modernos de governo, foram legados culturais essenciais para a construção do mundo ocidental da forma como o conhecemos hoje.

Mais de dois mil anos se passaram. No decorrer da história, o território grego foi dominado pelos romanos, bizantinos e turcos otomanos. Cada uma dessas grandes civilizações deixou traços indeléveis.

Com mais de dez milhões de habitantes, em sua maioria cristãos ortodoxos, a Grécia atual é um Estado laico, moderno e democrático. É também uma combalida integrante da União Europeia, bloco econômico, político e social que integra nações europeias e cujos objetivos são, entre outros, promover a unidade política e econômica do continente, melhorar as condições de vida dos cidadãos, bem como as condições de livre comércio entre os países membros, além de reduzir as desigualdades entre as regiões. Para atingir tais objetivos foi criada uma moeda única: o euro.

Mas a Grécia gastou mais do que podia. Em 2008 o mundo viveu mais uma das crises típicas do sistema capitalista. A Europa viu-se no meio do "furacão" e alguns países membros foram mais atingidos. Para a nação grega, particularmente, as consequências foram catastróficas. Em 2012, a crise se agravou.

A Grécia tem enfrentado muitas dificuldades para refinanciar suas dívidas e despertado preocupação entre investidores de todo o mundo sobre sua situação econômica. Mesmo com seguidos pacotes de ajustes e ajuda financeira externa, o futuro da Grécia ainda é incerto. A população tem manifestado seu descontentamento diante de planos de cortes de gastos, previdência e mais impostos, demissões de funcionários públicos e redução de salários, exigências da União Europeia e do Fundo Monetário Internacional para liberação de fundos de auxílio financeiro.

Em meio a todo esse transtorno, em outubro de 2012, o Comitê Nobel da Noruega anunciou que o Prêmio Nobel da Paz desse ano fora destinado à União Europeia. Segundo o jornal O Estado de São Paulo, em sua edição de 12/10/2012: “O júri destacou em sua justificativa as conquistas para 'o avanço da paz e a 
reconciliação' na Europa, assim como para o estabelecimento 'da democracia e dos direitos humanos' no continente".

Se considerarmos que as guerras mundiais — que trouxeram tanta destruição e sofrimento — deram trégua após a criação da União Europeia, daremos razão ao Comitê Nobel da Noruega.

Não tem sido fácil. A Grécia, particularmente, atravessa um momento muito difícil. A imprensa divulga diariamente notícias sobre os problemas enfrentados pelo país. Mas percebe-se vida e dinamismo entre os gregos. Eles estão buscando saídas. Assim, podemos pensar que um povo que foi capaz de revolucionar a história criando a democracia e a filosofia, também será capaz de encontrar soluções criativas para as dificuldades que enfrenta na atualidade.

\section{REFERÊNCIAS}

ABBAGNANO, N.. Dicionário de Filosofia. São Paulo: Martins Fontes, 2007.

AGOSTINI, C. de S.. Aristófanes e Platão: deformadores da democracia antiga. 2008. Dissertação (Mestrado em Filosofia) - Faculdade de Filosofia, Letras e Ciências Humanas, Universidade de São Paulo, São Paulo, 2008. Disponível em:

http://www.teses.usp.br/teses/disponiveis/8/8133/tde-15012009-144506/pt-br.php Acesso em: 29 nov. 2012.

ANDERSON, P.. O modo de produção escravista. In PINSKY, J. Textos 2: modos de produção na

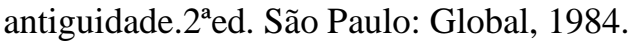

ARISTÓTELES, Metafísica. São Paulo: Paulus, 2002. p. 17-27.

AUDI, R. Dicionário de Filosofia de Cambridge. São Paulo: Paulus, 2006. p. 243-244.

CERQUEIRA, F.V. As origens do direito ocidental na pólis grega. Revista Justiça e História. Porto Alegre RS. v. 2, nº 3. 2002. Disponível em

http://www.tjrs.jus.br/export/poder_judiciario/historia/memorial do poder_judiciario/memorial judiciario gau cho/revista_justica_e_historia/issn_1676-5834/v2n3/doc/04-Fabio.PDF Acesso em: 19 nov. 2012.

FESTUGIÈRE, A. J. La libertad em la Grecia Antigua. Barcelona: Editorial Seix Barral S. A., 1953. p. 9-13.

FINLEY, M. I. Economia e sociedade na Grécia antiga. São Paulo: Marins Fontes, 1989.

FLORENZANO, M. B.B. O mundo antigo: economia e sociedade. São Paulo: 1994. p. 10.

Nascer, viver e morrer na Grécia antiga. São Paulo: Atual, 1996.

GIORDANI, M. C.. História da Grécia. Rio de Janeiro: Vozes, 1972. p. 28-100.

HAUSER, A.. História social da literatura e da arte. São Paulo: Martins Fontes, 2003.

HOMERO. Ilíada. Lisboa: Typographia Guttemberg, 1987, p.139.

Odisséia. São Paulo: Cultrix, 1997.

JAPIASSU, H e MARCONDES, D. Dicionário básico de filosofia. 5a ed. Rio de Janeiro; Zahar, 2008. LALANDE, A.. Vocabulário Técnico e Crítico de Filosofia. São Paulo: Martins Fontes, 1999. p.405.

MORA, F.. Dicionário de Filosofia. São Paulo: Loyola, 2004, p. 156-1081.

PRÊMIO Nobel da Paz fica com a União Europeia. O Estado de São Paulo. São Paulo. 12 nov. 2012. Disponível em: http://www.estadao.com.br/noticias/internacional,premio-nobel-da-paz-fica-com-a-uniaoeuropeia,944590,0.htm. Acesso: 24 out. 2012. 
REALE, G.. História da filosofia antiga: V. I. São Paulo: Loyola, 1993. p. 53-114.

SANTOS, G. V. dos. O lógos e a aísthesis como fundamentos da pólis no pensamento de Protágoras. Prometeus Filosofia em Revista. São Cristóvão - SE. Ano 5, nº 9, Jan.-Jun. 2012. Disponível em: http://200.17.141.110/periodicos/prometeus/9/6.pdf Acesso: 19 nov. 2012.

SILVA, V. G. e ANSAI, R. B. A importância da filosofia para a educação. In $8^{a}$ Mostra de Pós Graduação da Faculdade Estadual de Filosofia, Ciências e Letras de União da Vitória - PR. 2008. IEPS - FAFIUV. Disponível em: http://www.ieps.org.br/ARTIGO-FILOSOFIA.pdf Acesso: 18 nov. 2012 